Матеріали Всеукраїнської науково-практичної конференції «Актуальні питання діагностики, лікування, раціональної фармакотерапії, диспансеризації та реабілітації в практичі сімейного лікаря"

удК 616.12-008.331.1-06:616.37-002.2]-085.214.22/.814.1

DOI

\title{
ЕФЕКТИВНІСТЬ ПРЕПАРАТУ МЕБІКАР У ПОЄДНАННІ 3 РЕФЛЕКСОТЕРАПІЄЮ ПРИ ГІПЕРТОНІЧНІЙ ХВОРОБІ З СУПУТНІМ ХРОНІЧНИМ ПАНКРЕАТИТОМ
}

\author{
๑І. І. Медвідь, Л. С. Бабінець, І. О. Боровик
}

ДВНЗ «Тернопільський державний медичний університет імені І. Я. Горбачевського МОз України»

Вступ. Лікування пацієнтів із коморбідною патологією вимагає індивідуального підходу. Неухильне слідування протоколам без урахування особливостей конкретного хворого може призвести до погіршення клінічного стану та розвитку ускладнень. Вплив вегетативних та психоемоційних розладів на ефективність терапії обумовлює пошук дієвих засобів їх корекції.

Мета. Провести порівняльний аналіз лікувальних програм із включенням загальноприйнятого комплексу лікування (ЗКЛ), психотропного препарату Мебікар і курсу аплікатора Ляпка (АЛ) у хворих на гіпертонічну хворобу (ГХ) та супутній хронічний панкреатит (ХП).

Матеріали і методи дослідження. Обстежено 40 хворих на ГХ із супутнім ХП у фазі нестійкої ремісії та 15 практично здорових осіб. Група хворих була додатково поділена на три підгрупи: 10 осіб отримували виключно ЗКЛ згідно із прийнятими протоколами; 15 - отримували мебікар 500 мг двічі на добу протягом місяця; 15 - на додачу до ЗКЛ та мебікару додатково проходили курс аплікацій за методом Ляпка з 14 сеансів за гальмівним методом. Були застосовані опитувальники GSRS (Gastrointestinal Simptom Rating Scale), Спілбергера-Ханіна, Айзенка. Визначали рівні особистісної тривожності (ОТ), реактивної тривожності (РТ) та нейротизму.

Результати й обговорення. Поєднання ГХ і ХП супроводжувалось вираженою тривожністю та вкрай вираженим нейротизмом. ЗКЛ незначно вплинуло на психоемоційний стан. У пацієнтів, що додатково приймали мебікар, тривожність та нейротизм знизились до помірних значень (РТ - $(34,60 \pm 1,36)$ бали; ОТ - $(32,27 \pm 1,46)$ бали; нейротизм - $(10,27 \pm 0,62)$ бали). При включенні курсу аплікацій за методом Ляпка і прийомі мебікару тривожність зменшилась до низької (РТ $(28,40 \pm 1,56)$ бали; ОТ - $(27,87 \pm 1,17)$ бали, а емоційна лабільність нормалізувалась $((8,20 \pm 0,76)$ бали). При виключно ЗКЛ показники артеріального тиску покращились в середньому на 10,2 \%, результати опитувальника GSRS - на 21,6 \%. У групі 3 додатковим включенням мебікару значення систолічного та діастолічного артеріального тиску покращились в середньому на 16,5\%. Поєднання курсу аплікацій за методом Ляпка та мебікару із ЗКЛ викликало зниження артеріального тиску в середньому на $18,9 \%$, хоча цей вплив достовірно не відрізнявся від попередньої групи. Результати опитувальника GSRS у групі лікування з додаванням мебікару в середньому знизились на $41,9 \%$, а при додатковому використанні аплікатора Ляпка - на 54,6\%.

Висновок. Додаткове включення до ЗКЛ мебікару, а особливо посилення даної програми курсом АЛ зумовило вищий рівень позитивної динаміки наведених показників. Отримані дані свідчать про значну роль корекції вегетативних і психоемоційних порушень, на яку спрямовані досліджувані методи лікування, у перебігу ГХ із супутнім ХП.

Перспективи подальших досліджень. Застосування аналізу стану вегетативної нервової системи на основі показників варіабельності серцевого ритму в оцінці ефективності розглянутих терапевтичних комплексів. 